\title{
Pengaruh Kompetensi, Komitmen Organisasi Pemerintah Desa dan Partisipasi Penganggaranterhadap Akuntabilitas dalam Pengelolaan Dana Desa (Studi Empiris pada Pemerintah Desa di Kabupaten Buleleng Barat)
}

\author{
Komang Lia Santi Kasmini ${ }^{1 *}$, Nyoman Ayu Wulan Trisna Dewi ${ }^{2}$ \\ 12 Jurusan Ekonomi dan Akuntansi, Universitas Pendidikan Ganesha, Singaraja, Indonesia
} *komangliasantikasmini21@undiksha.ac.id ${ }^{1 *}$

\section{Abstrak}

Tujuan dari dilakukannya penelitian ini adalah untuk mengetahui pengaruh kompetensi, komitmen organisasi pemerintah desa dan partisipasi penganggaran terhadap akuntabilitas dalam pengelolaan dana desa. Metode yang digunakan dalam penelitian ini menggunakan metode kuantitatif. Data diperoleh melalui instrumen pengumpulan data berupa kuesioner yang diukur dengan skala likert. Populasi yang digunakan adalah pemerintah desa di Kabupaten Buleleng Barat yang terdiri dari Kecamatan Banjar, Kecamatan Seririt, Kecamatan Busungbiu dan Kecamatan Gerokgak. Untuk menentukan sampel menggunakan metode purposive sampling dengan kriteria responden adalah kepala desa, sekretaris desa dan kepala urusan keuangan desa dan didapat sebanyak 198 resonden dari total 66 desa. Analisis data pada penelitian ini menggunakan analisis deskriptif, pengukuran variabel, uji kualitas data, uji asumsi klasik, analisis regresi linier berganda, dan uji hipotesis dengan menggunakan SPSS. Hasil penelitian menunjukkan bahwa variabel kompetensi (X1), komitmen organisasi pemerintah desa (X2) dan partisipasi penganggaran (X3) berpengaruh positif dan signifikan terhadap akuntabilitas dalam pengelolaan dana desa.

Kata Kunci : Dana Desa, Akuntabilitas pengelolaan dana desa, Kompetensi, Komitmen Organisasi Pemerintah Desa, Pasrtisipasi Penganggaran.

\section{Abstract}

The purpose of this study was to determine the effect of competence, organizational commitment of the village government and budgetary participation on accountability in the management of village funds. The method used in this study uses quantitative methods. Data was obtained through a data collection instrument in the form of a questionnaire measured by a Likert scale. The population used is the village government in West Buleleng Regency which consists of Banjar District, Serinit District, Busungbiu District and Gerokgak District. To determine the sample using the purposive sampling method with the criteria of respondents being the village head, village secretary and head of village financial affairs and obtained as many as 198 respondents from a total of 66 villages. Data analysis in this study used descriptive analysis, variable measurement, data quality test, classical assumption test, multiple linear regression analysis, and hypothesis testing using SPSS. The results showed that the variables of competence (X1), village government organizational commitment (X2) and budgeting participation (X3) had a positive and significant effect on accountability in village fund management.

Keywords: Village Fund, Village Fund Management Accountability, Competence, Village Government Organizational Commitment, Budgeting Participation

\section{Pendahuluan}

Desa merupakan representasi dari kesatuan masyarakat hukum terkecil yang telah ada dan tumbuh berkembang seiring dengan sejarah kehidupan masyarakat Indonesia. Sebagai

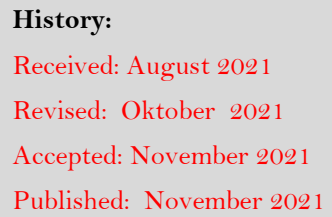

Publisher: Undiksha Press

Licensed: This work is licensed under

a Creative Commons Attribution 3.0 License

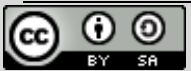


wujud pengakuan negara terhadap desa, khususnya dalam rangka memperjelas fungsi dan kewenangan desa, serta memperkuat kedudukan desa dan masyarakat desa sebagai subyek pembangunan, diperlukan kebijakan penataan dan pengaturan mengenai desa yang diwujudkan dengan lahirnya UU Nomor 6 Tahun 2014 tentang Desa.

Untuk mendukung pelaksanaan tugas dan fungsi desa dalam penyelenggaraan pemerintahan dan pembangunan desa dalam segala aspeknya sesuai dengan kewenangan yang dimiliki, UU Nomor 6 Tahun 2014 memberikan mandat kepada Pemerintah untuk mengalokasikan dana desa. Dana desa tersebut dianggarkan setiap tahun dalam APBN yang diberikan kepada setiap desa sebagai salah satu sumber pendapatan desa.

Yesinia (2018) berpendapat bahwa mengelola keuangan desa seharusnya dilakukan dengan berdasar pada transparansi, akuntabel dan partisipatif serta pelaksanaan yang tertib dan disiplin terhadap anggaran. Oleh karena itu pertanggungjawaban dana desa harus dilakukan dengan baik dan akuntabel. Akuntabilitas dalam pemerintah desa sangat penting.

Setiap pemerintah desa berupaya untuk memberikan yang terbaik bagi keberlangsungan masyarakat desa. Begitu pula dengan dana desa, semakin besar jumlah yang didapatkan maka semakin besar pula tanggung jawab yang harus diberikan. Bukan hanya tanggung jawab, akan tetapi indikasi untuk dilakukannya kecurangan atau penyelewengan dana desa juga semakin tinggi.

Berdasarkan data dari website DJPK Kemenkeu (www.djpk.kemenkeu.go.id). Pada tahun 2019 Kabupaten Buleleng dengan jumlah desa sebanyak 129 desa mendapatkan alokasi dana desa totalnya sebesar Rp124.026.738.000. Sedangkan pada tahun 2020 alokasi dana desa totalnya sebesar Rp127.185.229.000. Setiap tahun kucuran dana desa semakin meningkat nilainya. Khususnya Kabupaten Buleleng, dari sembilan kabupaten yang ada di Provinsi Bali, buleleng adalah kabupaten yang paling banyak mendapatkan dana desa ini dibanding dengan kabupaten lainnya.

Berdasarkan data dari website DJPK Kemenkeu, pada tahun 2019 Kabupaten Buleleng dengan jumlah desa sebanyak 129 desa mendapatkan alokasi dana desa totalnya sebesar Rp124.026.738.000. Sedangkan berdasarkan pada tabel 1.1 pada tahun 2020 alokasi dana desa totalnya sebesar Rp127.185.229.000. Setiap tahun kucuran dana desa semakin meningkat nilainya. Khususnya Kabupaten Buleleng, dari sembilan kabupaten yang ada di Provinsi Bali, buleleng adalah kabupaten yang paling banyak mendapatkan dana desa ini dibanding dengan kabupaten lainnya.

Menurut data dari Indonesia Corruption Watch (ICW) mencatat bahwa terdapat 169 kasus korupsi selama semester 1/2020. Dari jumlah tersebut, kasus korupsi di sektor anggaran dana desa yang paling banyak terjadi yakni sebanyak 44 kasus. Maka dari itu, Kabupaten Buleleng sebagai penerima dana desa yang paling banyak di Provinsi Bali lebih rentan dalam penyelewengan penggunaan keuangan desa. Beberapa tahun terakhir terjadi beberapa kasus korupsi dana desa yang terjadi di Kabupaten Buleleng.

Dari beberapa kasus penyalahgunaan dana desa yang terjadi di Kabupaten Buleleng sebagian besar kasus terjadi di Kabupaten Buleleng bagian Barat. Terdapat beberapa kecamatan yang tergolong ke dalam buleleng bagian barat yakni Kecamatan Banjar, Kecamatan Seririt, Kecamatan Busungbiu dan Kecamatan Gerokgak. Sehingga penelitian ini akan berfokus pada pemerintah desa di Kabupaten Buleleng Barat.

Penelitian ini ingin meneliti faktor-faktor yang mempengaruhi akuntabilitas dalam pengelolaan dana desa dengan teori stewardship sebagai grand teori dan menambahkan tiga variabel yakni kompetensi, komitmen organisasi pemerintah desa dan partisipasi penganggaran.

Berdasarkan pemaparan latar belakang permasalahan di atas, maka peneliti ingin membahas faktor yang memengaruhi akuntabilitas dalam pengelolaan dana desa dalam 
penelitian yang berjudul : "Pengaruh Kompetensi, Komitmen Organisasi Pemerintah Desa dan Partisipasi Penganggaran terhadap Akuntabilitas dalam Pengelolaan Dana Desa (Studi Empiris pada Pemerintah Desa di Kabupaten Buleleng Barat)".

Teori stewardship menggambarkan situasi bahwa manajemen tidaklah termotivasi oleh tujuan-tujuan individu tetapi lebih ditujukan pada sasaran hasil utama mereka untuk kepentingan organisasi. Teori tersebut mengasumsikan adanya hubungan yang kuat antara kepuasan dan kesuksesan organisasi. Kesuksesan organisasi menggambarkan maksimalisasi utilitas kelompok principals dan manajemen. Maksimalisasi utilitas kelompok ini pada akhirnya akan memaksimumkan kepentingan individu yang ada dalam kelompok organisasi. Digunakannya teori stewardship terhadap penelitian ini, dapat menjelaskan eksistensi pemerintah desa (steward) sebagai suatu lembaga yang dapat dipercaya dan bertindak sesuai dengan kepentingan publik dengan melaksanakan tugas dan fungsinya dengan tepat untuk kesejahteraan masyarakat.

Akuntabilitas adalah bentuk kewajiban mempertanggungjawabkan keberhasilan atau kegagalan pelaksanaan misi organisasi dalam mencapai tujuan dan sasaran yang telah ditetapkan sebelumnya melalui suatu media pertanggungjawaban yang dilaksanakan secara periodik Yesinia (2018). Akuntabilitas menjadi sebuah kontrol penuh aparatur atas segala sesuatu yang telah dilakukan dalam sebuah pemerintahan, sehingga peran pemerintah selaku agen menjadi sebuah faktor penting dalam mempertanggungjawabkan kinerja dari pemerintahan kepada prinsipal atau rakyat. Untuk mendukung keberhasilan akuntabilitas dan transparansi dalam sebuah pemerintahan maka banyak faktor yang dapat memengaruhi kedua aspek tersebut Widyatama (2017).

Kompetensi merupakan kemampuan yang dimiliki seseorang dalam mengerjakan tugas dan tanggung jawabnya pada bidang tertentu yang dibekali dengan kemampuan berpikir yang baik, dan bertindak secara konsisten. Abdul (2010) mengemukakan bahwa kompetensi berkaitan dengan sumber daya manusia. Dalam hal ini kompetensi sumber daya manusia adalah kemampuan seseorang dalam melaksanakan tugas dan tanggung jawab yang diberikan dengan bekal pendidikan, pelatihan, dan pengalaman yang cukup memadai. Kompetensi yang dimiliki oleh pengelola dana desa menjadi syarat utama agar akuntabilitas desa bisa berjalan denga maksimal. pelaksanaan pengelolaan dana desa sebagai akibat adanya desentralisasi fiskal yang diserahkan oleh pemerintah pusat kepada pemerintah daerah dan pemerintah daerah kepada pemerintah desa dibutuhkan persiapan.

Komitmen organisasi pemerintah desa merupakan rasa bertanggung jawab penuh terhadap tugas yang dilakukannya untuk tercapainya tujuan. Nurkhasanah (2019) menyebutkan bahwa dengan adanya komitmen organisasi dalam pemerintahan desa maka sumber daya manusia pada organisasi tersebut dapat berjalan secara maksimal dalam menciptakan akuntabilitas yang baik, komitmen organisasi bisa menjadikan ukuran sejauh mana pemerintah desa memihak organisasinya dan mempertahankan keanggotaannya dalam suatu organisasi. Pemerintah desa yang memiliki komitmen yang kuat di dalam dirinya dapat mendorong aparatur pemerintah desa untuk bekerja kerasa dan penuh tanggung jawab dalam melaksanakan tugasnya dan mencapai tujuan yang ditentukan oleh organisasi itu sendiri.

Partisipasi anggaran adalah proses di mana bawahan atau pelaksana anggaran diberikan kesempatan untuk terlibat dalam dan mempunyai pengaruh dalam proses penyusunan anggaran, partisipasi manajer dalam proses penganggaran mengarah kepada seberapa besar tingkat keterlibatan manajer dalam menyusun anggaran serta pelaksanaannya untuk mencapai target anggaran (Nurhayati, 2012). Partisipasi dalam proses penyusunan anggaran memberikan wewenang kepada para pimpinan satuan kerja pusat pertanggungjawaban untuk menetapkan isi anggaran mereka. Wewenang yang dimiliki ini memberikan peluang bagi partisipan untuk menyalahgunakan kewenangannya dalam mempermudah pencapaian 
anggaran sehingga dapat merugikan organisasi tersebut Fitra (2017). Maka dari itu dibutuhkan anggota yang berkompeten dalam melakukan penyusunan anggaran serta fungsi kontrol yang baik untuk menciptakan anggaran yang baik.

\section{Pengaruh Kompetensi terhadap Akuntabilitas dalam Pengelolaan Dana Desa}

Kompetensi merupakan kemampuan yang dimiliki seseorang dalam mengerjakan tugas dan tanggung jawabnya pada bidang tertentu yang dibekali dengan kemampuan berpikir yang baik, dan bertindak secara konsisten. Kompetensi perangkat desa adalah kemampuan yang dimiliki oleh perangkat desa dalam menjalankan tugas dan kewajibannya dalam melayani masyarakat.

Sejalan dengan teori stewardship, aparat yang bertugas sebagai pelayan memiliki kewajiban untuk melayani kepada masyarakat sebagai wujud akuntabilitas. Sehingga pada saat pengambilan keputusan dalam penggunaan dana desa akan menghasilkan keputusan yang terbaik guna memberikan pelayanan yang terbaik sesuai dengan tugas yang diharapkan.

Pada penelitian sebelumnya yang dilakukan oleh Kezia (2020), Sujatnika (2020) yang menguji pengaruh kompetensi perangkat terhadap akuntabilitas pengelolaan dana desa yang mendapatkan hasil bahwa kompetensi perangkat desa berpengaruh dan signifikan terhadap akuntabilitas pengelolaan dana desa. Sedangkan penelitian yang dilakukan oleh Rismawati (2019) yang menguji pengaruh kompetensi aparat pengelola dana desa terhadap akuntabilitas pengelolaan dana desa dan mendapatkan hasil bahwa kompetensi aparat pengelolaan dana desa tidak berpengaruh terhadap akuntabilitas dana desa.

Berdasarkan hal tersebut, maka hipotesis yang dikembangkan dalam penelitian ini sebagai berikut:

$\mathrm{H}_{1} \quad$ : Kompetensi berpengaruh terhadap Akuntabilitas dalam pengelolaan dana desa.

\section{Pengaruh Komitmen Organisasi Pemerintah Desa terhadap Akuntabilitas dalam Pengelolaan Dana Desa}

Komitmen organisasi pemerintah desa merupakan rasa bertanggung jawab penuh terhadap tugas yang dilakukannya untuk tercapainya tujuan. Dengan komitmen yang tinggi dapat menghasilkan anggota yang menjunjung tinggi kejujuran dan lebih mengendepankan kepentingan organisasi dibandingkan dengan kepentingan individu. Hal ini sejalan dengan teori stewardship yang mana organisasi tidak termotivasi oleh tujuan-tujuan invidu melainkan lebih mengedepankan tujuan untuk kepentingan organisasi.

Penelitian terdahulu yang dilakukan oleh Ladapase (2019) mendapatkan hasil bahwa kompetensi aparatur berpengaruh terhadap akuntabilitas pengelolaan dana desa. Sedangkan penelitian yang dilakukan oleh Nurkhasanah (2019) mendapatkan hasil bahwa komitmen organisasi pemerintah desa tidak berpengaruh terhadap akuntabilitas pengelolaan dana desa.

Berdasarkan uraian tersebut, maka dapat dirumuskan hipotesis sebagai berikut:

$\mathrm{H}_{2}$ : Komitmen Organisasi Pemerintah Desa berpengaruh positif terhadap Akuntabilitas pengelolaan dana desa.

Pengaruh Partisipasi Penganggaran terhadap Akuntabilitas dalam Pengelolaan Dana Desa

Anggaran adalah pernyataan mengenai estimasi kinerja yang ingin dicapai dalma periode tertentu yang dinyatakan dalam ukuran finansial. Penganggaran juga dikatakan sebagai proses atau metode untuk mempersiapkan suatu angaran. Penganggaran dalam organisasi sektor publik merupakan tahapan yang cukup rumit dan mengandung nuansa politik yang tinggi. Berdasarkan teori stewardship, adanya partisipasi dari principals dalam melakukan perencanaan anggaran terkait dana desa agar anggaran yang dibuat selaras dengan tujuan yang ingin dicapai. Partisipasi peganggaran dalam penyusunan anggaran, menjadikan 
anggaran yang direncanakan lebih transparan sehingga akan menghindari adanya kecurangan dan manipulasi.

Penelitian terdahulu yang dilakukan oleh Sugiarti (2020) menguji pengaruh partisipasi penganggaran terhadap akuntabilitas pengelolaan dana desa dan mendapatkan hasil bahwa partisipasi anggaran berpengaruh positif signifikan terhadap akuntabilitas pengelolaan dana desa. Sedangkan penelitian yang dilakukan oleh Anggraeni dan Yuliani (2019) yang menguji pengaruh partisipasi penganggaran dan mendapatkan hasil partisipasi penganggaran tidak berpengaruh terhadap akuntabilitas pengelolaan dana desa.

Berdasarkan beberapa penelitian yang menggunakan variabel partisipasi penganggaran maka dapat dirumuskan hipotesis sebagai berikut:

$\mathrm{H}_{3}$ :Partisipasi Anggaran berpengaruh terhadap Akuntabilitas pengelolaan dana desa.

\section{Metode}

Penelitian ini menggunakan rancangan penelitian kuantitatif yakni penelitian yang berfokus pada analisis data dalam bentuk angka yang dalam pengujian hipotesisnya dianalisis menggunakan metode statistik. Populasi dalam penelitian ini adalah pemerintah desa di Kabupaten Buleleng Barat yang terdiri dari Kecamatan Banjar, Kecamatan Seririt, Kecamatan Busungbiu dan Kecamatan Gerokgak yang berjumlah sebanyak 66 desa. Dipilih nya Kabupaten Buleleng Barat karena beberapa kasus akuntabilitas yang rendah terjadi di beberapa desa pada Kabupaten Buleleng Barat.

Teknik sampling yang digunakan adalah pemilihan sampel menggunakan metode purposive sampling dengan kriteria responden yaitu kepala desa, sekretaris desa dan kaur keuangan desa dengan minimal pendidikan SMA/SMK dan menjabat minimal 2 tahun.

Pengumpulan data yang digunakan pada penelitian ini diawali dengan proses observasi dan kemudian menyebar kuesioner. Kuesioner adalah daftar pertanyaan tertulis yang disusun oleh peneliti yang ditunjukkan kepada responden untuk mencari jawaban dari rumusan masalah yang peneliti tetapkan. Kuesioner akan disebarkan secara langsung berupa lembaran kertas dan juga menggunakan google form. Skala yang dipakai pada penelitian ini yakni skala likert. Skala likert digunakan untuk mengukur pendapat, sikap serta pemahaman individu atau kelompok mengenai kejadian sosial (Sugiyono, 2017). Data yang telah terkumpul kemudian dianalisis menggunakan bantuan aplikasi SPSS dengan melalui beberapa uji diantaranya analisis statistik deskriptif, pengukuran variabel, uji instrumen, uji asumsi klasik, dan uji hipotesis. Hasil analisis kemudian diinterpretasikan ke dalam pembahasan yang kemudian dilakukan penarikan kesimpulan dan saran.

\section{Hasil dan Pembahasan}

Hasil Uji Statistik Deskriptif

Tabel 1. Hasil Analisis Deskriptif

\begin{tabular}{cccccc}
\hline & N & Minimum & Maximum & Mean & $\begin{array}{c}\text { Std. } \\
\text { Deviation }\end{array}$ \\
\hline Kompetensi (X1) & 198 & 40 & 50 & 46.24 & 3.089 \\
Komitmen Organisasi Pemerintah Desa (X2) & 198 & 20 & 30 & 25.52 & 2.062 \\
Partisipasi Penganggaran (X3) & 198 & 20 & 30 & 25.05 & 2.506 \\
Akuntabilitas Pengelolaan Dana Desa (Y) & 198 & 40 & 50 & 46.17 & 3.520 \\
\hline
\end{tabular}

Sumber : Data Diolah, 2021

Berdasarkan Tabel 1 menunjukkan bahwa $\mathrm{N}$ atau jumlah data setiap variabel yang valid berjumlah 198. Variabel akuntabilitas pengelolaan dana desa (Y) yang terdiri dari 198 data 
sampel mempunyai nilai minimum 40 , nilai maksimum 50 , nilai mean 46.17 , serta nilai standar deviasi 3.520 yang artinya nilai mean lebih besar dari nilai standar deviasi sehingga ini mengindikasikan rendahnya penyimpangan data. Penyimpangan data yang rendah menunjukkan bahwa sudah meratanya penyebaran nilai data.

Variabel kompetensi (X1) yang terdiri dari 198 sampel, diketahui bahwa nilai minimumnya sebesar 40 , nilai maksimum 50 , nilai mean 46.24 , serta nilai standar deviasi 3.089 yang artinya nilai mean lebih besar dari nilai standar deviasi sehingga ini mengindikasikan rendahnya penyimpangan data. Penyimpangan data yang rendah menunjukkan bahwa sudah meratanya penyebaran nilai data.

Tabel 2. Hasil Analisis Linier Berganda dan Uji T

\begin{tabular}{lccccc}
\hline \multirow{2}{*}{ Model } & \multicolumn{2}{c}{$\begin{array}{c}\text { Unstandardized } \\
\text { Coefficients }\end{array}$} & $\begin{array}{c}\text { Standardized } \\
\text { Coefficients }\end{array}$ & \multirow{2}{*}{ Sig. } \\
\cline { 2 - 5 } & B & Std. & Beta & & \\
\cline { 2 - 5 }$($ Constant) & 8.640 & 2.772 & & 3.116 & .002 \\
Kompetensi (X1) & .451 & .077 & .396 & 5.837 & .000 \\
$\begin{array}{l}\text { Komitmen Organisasi } \\
\text { Pemerintah Desa (X2) }\end{array}$ & .233 & .107 & .137 & 2.175 & .031 \\
$\begin{array}{l}\text { Partisipasi } \\
\text { Penganggaran (X3) }\end{array}$ & .428 & .089 & .305 & 4.794 & .000 \\
\hline
\end{tabular}

Sumber : Data Diolah, 2021

Variabel komitmen organisasi pemerintah desa (X2) yang terdiri dari 198 sampel, diketahui bahwa nilai minimumnya 20 , nilai maksimum 30 , nilai mean 25.52 , serta nilai standar deviasi 2.062 yang artinya nilai mean lebih besar dari nilaistandar deviasi sehingga ini mengindikasikan rendahnya penyimpangan data. Penyimpangan data yang rendah menunjukkan bahwa sudah meratanya penyebaran nilai data.

Variabel partisipasi penganggaran (X3) yang terdiri dari 198 sampel, diketahui bahwa nilai minimumnya sebesar 20 , nilai maksimum 30 , nilai mean 25,05 , serta nilai standar deviasi 2.506 yang artinya nilai mean lebih besar dari nilai standar deviasi yang menunjukkan rendahnya penyimpangan data. Penyimpangan data yang rendah menunjukkan bahwa sudah meratanya penyebaran nilai data.

\section{Hasil Analisis Linier Berganda}

Berdasarkan data pada tabel 2 dapat dimasukkan ke dalam persamaan regresi berikut :

$\mathrm{Y} 1=\mathrm{a}+\mathrm{b} 1 \mathrm{X} 1+\mathrm{b} 2 \mathrm{X} 2+\mathrm{b} 3 \mathrm{X} 3+\mathrm{e}$

$\mathrm{Y} 1=8.640+0.451 \mathrm{X} 1+0.233 \mathrm{X} 2+0.428 \mathrm{X} 3+2.772$ berikut:

Berdasarkan model regresi yang terbentuk, dapat diinterpretasikan hasil sebagai

1. Konstanta 8.640 menunjukkan hasil bahwa variabel kompetensi (X1), komitmen organisasi pemerintah (X2) dan partisipasi penganggaran (X3) maka variabel akuntabilitas pengelolaan dana desa (Y) memiliki nilai 8.640 satuan.

2. Kompetensi (X1) memiliki koefisien regresi senilai 0,451 . Nilai koefisien regresi yang positif menunjukkan bahwa kompetensi (X1) memiliki pengaruh positif terhadap akuntabilitas pengelolaan dana desa (Y). Hal ini menggambarkan bahwa setiap 
kenaikan 1 satuan pada kompetensi (X1) dapat meningkatkan akuntabilitas pengelolaan dana desa (Y) sebesar 0,451 satuan dengan asumsi variabel independen yang lainnya tetap.

3. Komitmen Organisasi Pemerintah Desa (X2) memiliki koefisien regresi senilai 0,233 Nilai koefisien regresi yang positif menunjukkan bahwa komitmen organisasi pemerintah desa (X2) memiliki pengaruh positif terhadap akuntabilitas pengelolaan dana desa (Y). Hal ini menggambarkan bahwa setiap kenaikan 1 satuan pada komitmen organisasi pemerintah desa (X2) dapat meningkatkan akuntabilitas pengelolaan dana desa $(\mathrm{Y})$ sebesar 0,233 satuan dengan asumsi variabel independen yang lainnya tetap.

4. Partisipasi Penganggaran (X3) memiliki koefisien regresi senilai 0,428. Nilai koefisien regresi yang positif menunjukkan bahwa partisipasi penganggaran (X3) memilih pengaruh positif terhadap akuntabilitas pengelolaan dana desa (Y). Hal ini menggambarkan bahwa setiap kenaikan 1 satuan pada partisipasi penganggaran (X3) dapat meningkatkan akuntabilitas pengelolaan dana desa (Y) sebesar 0,428 satuan dengan asumsi variabel independen yang lainnya tetap.

Sesuai dengan tabel 2 yang telah disajikan di atas dapat diketahui hasil pengujian hipotesis sebagai berikut :

\section{Uji Hipotesis $1\left(H_{1}\right)$}

Hasil pengujian hipotesis pertama terlihat pada kolom $t$ dan sig variabel kompetensi (X1) memiliki nilai thitung sebesar 5.837 dan signifikansi 0,000. Hal tersebut menunjukkan bahwa thitung $5.837>$ nilai ttabel 1.972 dan nilai signifikansi $0,000<0,05$. Nilai thitung yang positif dan lebih besar dari pada ttabel serta nilai signifikansi yang kurang dari 0,05 berarti bahwa variabel kompetensi (X1) mempunyai pengaruh dan hubungan yang searah terhadap akuntabilitas pengelolaan dana desa (Y). Jadi dapat disimpulkan bahwa H1 diterima, yaitu kompetensi (X1) berpengaruh secara signifikan terhadap akuntabilitas pengelolaan dana desa (Y).

\section{Uji Hipotesis $2\left(\mathrm{H}_{2}\right)$}

Hasil pengujian hipotesis kedua terlihat pada kolom t dan sig variabel komitmen organisasi pemerintah desa (X2) memiliki nilai thitung sebesar 2.175 dan signifikansi 0,031 . Hal tersebut menunjukkan bahwa thitung $2.175>$ nilai ttabel 1.972 dan nilai signifikansi $0,031<0,05$. Nilai thitung yang positif dan lebih besar dari pada ttabel serta nilai signifikansi yang kurang dari 0,05 berarti bahwa variabel komitmen organisasi pemerintah desa (X2) mempunyai pengaruh dan hubungan yang searah dengan akuntabilitas pengelolaan dana desa (Y). Jadi dapat disimpulkan bahwa $\mathrm{H} 2$ diterima, yaitu komitmen organisasi pemerintah desa (X2) berpengaruh secara signifikan terhadap akuntabilitas pengelolaan dana desa (Y).

\section{Uji Hipotesis $3\left(\mathrm{H}_{3}\right)$}

Hasil pengujian hipotesis ketiga terlihat pada kolom t dan sig variabel partisipasi penganggaran (X3) memiliki nilai thitung sebesar 4.794 dan signifikansi 0,000. Hal tersebut menunjukkan bahwa thitung $4.794>$ nilai ttabel 1.972 dan nilai signifikansi $0,000<0,05$. Nilai thitung yang positif dan lebih besar dari pada ttabel serta nilai signifikansi yang kurang dari 0,05 berarti bahwa variabel partisipasi penganggaran (X3) mempunyai pengaruh dan hubungan yang searah dengan akuntabilitas pengelolaan dana desa (Y). Jadi dapat disimpulkan bahwa $\mathrm{H} 3$ diterima, yaitu partisipasi penganggaran (X3) berpengaruh secara signifikan terhadap akuntabilitas pengelolaan dana desa (Y). 
Hasil Uji Koefisien Determinasi

Tabel 3. Hasil Uji Koefisien Determinasi (Adjusted R Square)

\begin{tabular}{|l|r|r|r|r|}
\hline Model & $\mathrm{R}$ & R Square & Adjusted R Square & Std. Error of the Estimate \\
\hline 1 & $.716 \mathrm{a}$ & .512 & .505 & 2.477 \\
\hline
\end{tabular}

Sumber : Data Diolah, 2021

Berdasarkan tabel 3 dapat diketahui bahwa koefisien determinasi yang dilihat dari Adjusted R Square senilai 0,505. Hal ini menunjukkan bahwa 50\% akuntabilitas pengelolaan dana desa dipengaruhi oleh variabel kompetensi, komitmen organisasi pemerintah desa dan partisipasi penganggaran. Sedangkan sisanya 50\% dipengaruhi oleh faktor lain di luar penelitian ini yang dapat memengaruhi akuntabilitas pengelolaan dana desa.

\section{Pengaruh Kompetensi terhadap Akuntabilitas Pengelolaan Dana Desa}

Berdasarkan uji regresi linier berganda, variabel kompetensi memiliki koefisien regresi senilai 0,451. Nilai koefisien regresi yang positif menunjukkan bahwa kompetensi berpengaruh positif terhadap akuntabilitas pengelolaan dana desa. Hal ini menggambarkan bahwa setiap kenaikan 1 satuan pada variabel komitmen dapat meningkatkan akuntabilitas pengelolaan dana desa (Y) sebesar 0,451 satuan dengan asumsi variabel independen yang lainnya tetap.

Pada pengujian hipotesis pada kolom t dan sig variabel kompetensi memiliki nilai thitung sebesar 5.837 dan signifikansi 0,000. Hal tersebut menunjukkan bahwa thitung 5.837 $>$ nilai ttabel 1.972 dan nilai signifikansi $0,000<0,05$. Nilai thitung yang positif dan lebih besar dari pada ttabel serta nilai signifikansi yang kurang dari 0,05 berarti bahwa variabel kompetensi mempunyai pengaruh dan hubungan yang searah terhadap akuntabilitas pengelolaan dana desa. Jadi dapat disimpulkan bahwa H1 diterima, yaitu kompetensi berpengaruh secara signifikan terhadap akuntabilitas pengelolaan dana desa.

Hasil penelitian ini didukung oleh teori stewardship yang mana manajemen pemerintahan dituntut untuk memberikan pelayanan (steward) bagi kepentingan masyarakat (principal) dan lebih mengedepankan tujuan organisasi.

Maka kompetensi aparatur desa sangat berperan penting dalam memberikan pelayanan yang baik kepada masyarakat. Aulia (2018) menyatakan bahwa semakin baik kompetensi aparat pengelola dana desa maka semakin baik pula akuntabilitas pengelolaannya.

Hasil penelitian ini juga didukung oleh beberapa hasil penelitian terdahulu Kezia (2020), Sujatnika (2020), Ladapase (2019), Sugiarti (2020), Mada dkk (2017), Widyatama (2017) dan Sapartiningsih (2019) yang mendapatkan hasil bahwa kompetensi berpengaruh signifikan positif terhadap akuntabilitas pengelolaan dana desa.

\section{Pengaruh Komitmen Organisasi Pemerintah Desa terhadap Akuntabilitas Pengelolaan Dana Desa}

Berdasarkan hasil dari uji regresi linier berganda, variabel komitmen organisasi pemerintah desa memiliki koefisien regresi senilai 0,233 Nilai koefisien regresi yang positif menunjukkan bahwa variabel komitmen organisasi pemerintah desa memiliki pengaruh positif terhadap akuntabilitas pengelolaan dana desa. Hal ini menggambarkan bahwa setiap kenaikan 1 satuan pada komitmen organisasi pemerintah desa dapat meningkatkan akuntabilitas pengelolaan dana desa sebesar 0,233 satuan dengan asumsi variabel independen yang lainnya tetap. 
Pada hasil pengujian hipotesis penelitian, terlihat pada kolom $t$ dan sig variabel komitmen organisasi pemerintah desa memiliki nilai thitung sebesar 2.175 dan signifikansi 0,031 . Hal tersebut menunjukkan bahwa thitung $2.175>$ nilai ttabel 1.972 dan nilai signifikansi $0,031<0,05$. Nilai thitung yang positif dan lebih besar dari pada ttabel serta nilai signifikansi yang kurang dari 0,05 berarti bahwa variabel komitmen organisasi pemerintah desa mempunyai pengaruh dan hubungan yang searah dengan akuntabilitas pengelolaan dana desa. Jadi dapat disimpulkan bahwa (H2) diterima, yaitu komitmen organisasi pemerintah desa berpengaruh secara signifikan terhadap akuntabilitas pengelolaan dana desa.

Hasil penelitian ini juga didukung oleh teori stewardship yang mana teori ini menggambarkan bahwa pemerintah desa lebih mengedepankan kepentingan organisasi dibandingkan dengan kepentingan individu maka dari itu dengan komitmen organisasi pemerintah desa yang baik akan mempermudah dalam mencapai tujuan dari organisasi pemerintah salah satunya yaitu mewujudkan akuntabilitas pengelolaan dana desa. Hasil penelitian ini juga didukung oleh beberapa penelitian terdahulu yaitu penelitian yang dilakukan oleh Ladapase (2019), Rismawati (2019) dan Mada dkk (2017) yang mendapatkan hasil bahwa komitmen organisasi pemerintah desa berpengaruh signifikan positif terhadap akuntabilitas dalam pengelolaan dana desa.

\section{Pengaruh Partisipasi Peganggaran terhadap Akuntabilitas Pengelolaan Dana Desa}

Berdasarkan hasil dari uji regresi linier berganda,variabel partisipasi penganggaran memiliki koefisien regresi senilai 0,428. Nilai koefisien regresi yang positif menunjukkan bahwa partisipasi penganggaran memiliki pengaruh positif terhadap akuntabilitas pengelolaan dana desa. Hal ini menggambarkan bahwa setiap kenaikan 1 satuan pada partisipasi penganggaran dapat meningkatkan akuntabilitas pengelolaan dana desa sebesar 0,428 satuan dengan asumsi variabel independen yang lainnya tetap.

Sementara hasil dari pengujian hipotesis variabel partisipasi penganggaran terlihat pada kolom t dan sig variabel partisipasi penganggaran memiliki nilai thitung sebesar 4.794 dan signifikansi 0,000. Hal tersebut menunjukkan bahwa thitung $4.794>$ nilai tabel 1.972 dan nilai signifikansi $0,000<0,05$. Nilai thitung yang positif dan lebih besar dari pada ttabel serta nilai signifikansi yang kurang dari 0,05 berarti bahwa variabel partisipasi penganggaran mempunyai pengaruh dan hubungan yang searah dengan akuntabilitas pengelolaan dana desa. Jadi dapat disimpulkan bahwa (H3) diterima, yaitu partisipasi penganggaran berpengaruh secara signifikan terhadap akuntabilitas pengelolaan dana desa.

Penelitian ini didukung juga oleh teori stewardship yang menyatakan bahwa organisasi pemerintah lebih mengutamakan kepentingan organisasi dibanding dengan kepentingan individu, sehingga dalam hal ini, dengan adanya partisipasi dari principals dalam melakukan perencanaan anggaran terkait dana desa menjadikan anggaran yang dibuat selaras dengan tujuan yang ingin dicapai yaitu tujuan untuk kepentingan organisasi sehingga menciptakan akuntabilitas dalam pengelolaan dana desa yang mana merupakan tujuan dari teori stewardship.

Hasil penelitian ini juga didukung oleh beberapa penelitian terdahulu yaitu penelitian yang dilakukan oleh Rismawati (2019), Sugiarti (2020) dan Nurkhasanah (2019) yang mendapatkan hasil bahwa partisipasi penganggaran berpengaruh signifikan positif terhadap akuntabilitas dalam pengelolaan dana desa.

\section{Simpulan dan Saran}

Merujuk pada rumusan masalah penelitian, hasil analisis serta pembahasan sebelumnya, simpulan yang bisa ditarik yakni 1) Kompetensi berpengaruh positif dan signifikan terhadap akuntabilitas dalam pengelolaan dana desa pada pemerintah desa di Kabupaten Buleleng 
Barat, 2) Komitmen organisasi pemerintah desa berpengaruh positif dan signifikan terhadap akuntabilitas dalam pengelolaan dana desa pada pemerintah desa di Kabupaten Buleleng Barat, 3) Partisipasi Penganggaran berpengaruh positif dan signifikan terhadap akuntabilitas dalam pengelolaan dana desa pada pemerintah desa di Kabupaten Buleleng Barat.

Pada penelitian kali ini memiliki keterbatasan yaitu pada sampel yang digunakan hanya mencakup pada empat kecamatan yang terdapat di Kabupaten Buleleng dengan jumlah 66 desa. Sementara itu masih terdapat lima kecamatan lainnya yang masih bisa diteliti mengenai akuntabilitas pengelolaan dana desa karena cakupan akuntabilitas sangat luas. Sehingga dapat dikatakan penelitian ini belum dapat digeneralisasi pada desa di Kabupaten Buleleng, pada penelitian ini juga memiliki keterbatasan pada variabel yang digunakan yang mana variabel yang diteliti hanya tiga yakni variabel kompetensi, komitmen organisasi pemerintah desa dan partisipasi penganggaran. Sedangkan pada hasil penelitian ini dinyatakan masih terdapat 50\% variabel lain yang mempengaruhi akuntabilitas pengelolaan dana desa yang perlu ditinjau kembali agar adanya keterbaruan penelitian.

Saran yang bisa diberikan dengan merujuk pada hasil penelitian serta pembahasan di atas, yakni disarankan kepada pemerintah desa di Kabupaten Buleleng Barat agar mampu meningkatkan kualitas SDM dan tetap dapat mempertahankan akuntabilitas dalam pengelolaan dana desa agar tepat guna dan sesuai dengan yang diharapkan oleh pemerintah pusat dan untuk penelitian selanjutnya, disarankan untuk menambahkan variabel lainnya yang berpotensi berpengaruh terhadap akuntabilitas pengelolaan dana desa. Dari hasil penelitian yang telah dilakukan masih terdapat 50\% variabel yang mempengaruhi akuntabilitas pengelolaan dana desa diluar dari variabel yang digunakan dalam penelitian ini. Beberapa variabel tersebut seperti variabel audit kinerja, variabel kejelasan sasaran anggaran dan variabel pengawasan untuk keterbaruan penelitian selanjutnya.

\section{Daftar Pustaka}

Abdul, Kharis. (2010). Pengaruh Kualitas Sumber Daya Manusia Terhadap Pelaksanaan Sistem Pengendalian Intern Pada PT. AVIA AVIAN. Tesis. Jawa Timur: Fakultas Ekonomi Universitas Pembangunan Nasional.

Aulia, P. (2018). Pengaruh Kompetensi Aparat Pengelola Dana Desa, Komitmen Organisasi Pemerintah Desa, Pemanfaatan Teknologi Informasi, dan Partisipasi Masyarakat terhadap Akuntabilitas Pengelolaan Dana Desa di Kabupaten 50 Kota. JOM FEB. 1 (1): $1-15$.

Fitra, Ilham. (2017). Pengaruh Partisipasi Anggaran Kejelasan Sasaran Anggaran dan Komitmen Organisasi Terhadap Budgetary Slack (Studi Empiris Pada SKPD Kota Payakumbuh). Jurnal Akuntansi, 5(2).

Nurkhasanah, I. (2019). Pengaruh Kompetensi Sumber Daya Manusia, Pemanfaatan Teknologi Informasi, Partisipasi Penganggaran, Pengawasan, Dan Komitmen Organisasi Pemerintah Desa Terhadap Akuntabilitas Pengelolaan Dana Desa (Doctoral Dissertation, Skripsi, Universitas Muhammadiyah Magelang).

Sugiyono. (2017). Metode Penelitian Kuantitatif, Kualitatif, Dan R\&D. Bandung: Alfabeta

Widyatama, Arif, Lola Novita, dan D. (2017). Pengaruh Kompetensi dan Pengendalian Internal Terhadap Akuntabilitas Pemerintah Desa dalam Mengelola Alokasi Dana Desa (ADD). Jurnal Akuntansi Dan Keuangan Indonesia, 02(02).

Yesinia, Nur ida, Yuliarti \& Puspitasari. D. (2018). Analisis Faktor Yang Mempengaruhi Akuntabilitas Pengelolaan Alokasi Dana Desa (Studi Kasus Pada Kecamatan 
Yosowilangun Kabupaten Lumajang). Jurnal Aset (Akuntansi Riset). 10(1). 105-112

Kotler, P., \& Amstrong, G. (2012). Principles of Marketing. New Jersey: Prenctice Hall. 